\title{
Knowledge Management Enablers and Barriers in the Army: An Interpretive Structural Modeling Approach
}

\author{
Asha Nagendra ${ }^{1}$ and Srinivasan Morappakkam² \\ 'Symbiosis Institute Management Studies, Pune - 411020, Maharashtra, India; asha.nagendra@sims.edu \\ 25ymbiosis International University, Pune - 411020, Maharashtra, India; sri.indusri@gmail.com
}

\begin{abstract}
Background: Lately, Knowledge Management (KM) is an essential component of decisions and outcomes. Thus, large number of organizations aspires to implement KM. However, there are a few factors known as Knowledge Management Enablers and Barriers, henceforth, referred to as EBs which affect KM.Similarly, it would be imperative that these facets be analysed and tested in a closed environment like the Army. Objective:This paper studiesthe basic relationships amongst the shortlistedEBs. It also triesto understand their inter-se priorities and to identify those which are pivotal and drive others and also those which are driven. Methods andAnalysis: Interpretive Structural Modeling (ISM) has been adopted for this study. The inter-se and inter relationships between the EBsdistinctly emerged from the study. These EBs werethen categorised, based on their ability to drive othersor their dependence on others. Ultimately,how critical each factor is for the success of KM in the army environment was identified. Conclusion/ Further Study: Enablers and Barriers are the key in the KM implementation process. Conclusively, all nine EBs are relevant although they exhibit a varying degree of relative importance. Future study, could quantify the framework obtained from ISM model, using Analytical Hierarchy Process (AHP). Then focus on sub-centres of each factor having Driving and Dependence Powers, and how they will impact and also give the impetus, for KM to succeed.
\end{abstract}

Keywords: Barriers, Enablers, ISM, Knowledge Management, Micmac Analysis

\section{Introduction}

Knowledge Management has assumed great importance in performance of institutions]" "Organizational knowledge is the most important capital of current century organizations' ' $^{\prime}$ as expressed by 2014. Development of technology influenced KMㄱ. in 2008 identified that "KM is the renaissance of thinking, creating, sharing, leveraging and applying the knowledge, expertise and intellectual capital to retain knowledge before employees leave the

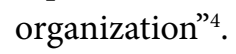

$\mathrm{KM}$ is a combination of complex techniques/ which range from systematic processes which could be formal or informal as brought out by ${ }^{6-9}$. These are now exploited by establishments to nurturefo and propagate knowledge across the organization 11 utilising technologies.

Knowledge gained on military aspects over centuries gradually consolidates itself as the primary source of
Knowledge management in the army. This aspect has been incorporated into training and doctrine. At the functional level, a great amount of knowledge is acquired and consolidated; however, tacit knowledge is regularly lost when experienced people retire.

Interpretive Structural Modeling (ISM) is a standard practise or a tool to handle complex interrelated issues to define inter-se / relative importance ${ }^{12,13}$. Experts assisted in developing the relationship matrix, culminating inan ISM model.

\section{Objective}

This study aims to identify the Enablers and Barriers (EBs) of KM, their relationship and impact as critical success factors in the implementation of KM in the Army using Interpretive Structural Modeling Technique.

The Organised based on ISM Modelling and Enablers/

*Author for correspondence 
Barriers of KM. The key words used for literature search were enablers and barriers of Knowledge Management, ISM, Driving and Dependence Power. In the process their definitions, factors / enablers have been dwelt upon.

\subsection{Specific Areas of Review}

In depth understanding of Knowledge Management, its enablers and barriers, related issues published so far and to analyse a comprehensive relationship using ISM.

The definition of KM as applicable to this studyis "systematic, organized, explicit and deliberate on-going process of creating, disseminating, applying, renewing and updating the knowledge for achieving organizational objectives" 1 .

\subsubsection{Knowledge Management Processes}

For the present study, we adopt "Knowledge Acquisition (KA), Knowledge Creation (KC), Knowledge Storage (KST) and Knowledge Sharing (KSH)" processes proposed by 1 in view of its comprehensiveness with a slight modification of notations.

\subsection{Organizations operating in a Closed- environment}

Focus on knowledge resources has been a major method of gaining a strategic advantage 1 . Organizations operating in a closed information environment have the requirement to maintain high security. To allow free flow of knowledge and information presents a considerable challenget.

Military transformation means evolution of "a knowledge and network based organization" and this would be the primary Military knowledge Management strategy:. KM in the defence environment would result in rational decisions in operations and logistics including aid to civil authorities.

Knowledge management in the army encompasses the power of group knowledge nurtured by creating, collecting and compiling, then organizing, finally, sharing and transferring ${ }^{1 / 2}$.

In 1 exemplify "in a military environment knowledge is sometimes needed in more mission-critical situations like a battlefield, where real-time decisions can have life or death consequences and where knowledge delivered late is useless".

"The contributions of military organizations to societal knowledge touch nearly every aspect of human endeavours."in?

Time tested Processes, Standard Operating Procedures (SOPs), hierarchy and Leadership to steer it is dominant in a closed environment. 2 ?

Although Erwin and Tiron'2 reported that the US Army had been one of the most fervent adopters of knowledge management. In contrast, limited information is available, of other national military organizations practicing knowledge management.

\subsection{Identifying the Enablers and Barriers}

Subsequent paragraphs dwell on the comprehensive list of enablers and barriers identified.

\subsubsection{Enablers}

Enablers, as applicable to a Closed Environment are Organisation culture; Leadership, People and technology $3^{33}$ are listed. Please refer Table 1. List of Enablers.

Table 1. List of enablers ${ }^{2-32}$

\begin{tabular}{|l|l|}
\hline Author & En ablers \\
\hline $\begin{array}{l}\text { Arthur Anderson (1996) } \\
\text { APQ } 1996 \text { \& 1999) }\end{array}$ & Leadership, corporate culture and IT infrastructure measures for assessing performance. \\
\hline Earl(1997) & Information Technology, HR \& organisation culture. \\
\hline Skyme \& Amidon(1997) & $\begin{array}{l}\text { Knowledge leadership includes: Vision, knowledge creating and sharing culture. Continuous learn- } \\
\text { ing, Technology infrastructure. }\end{array}$ \\
\hline Holsapple \& Joshi(1997) & Managers, Resources such as technology and infrastructure and working environment. \\
\hline Davenport et al.(1998) & $\begin{array}{l}\text { Knowledge structure, transfer, organizational culture, motivational practices, technical \& organiza- } \\
\text { tional infrastructure, \& senior management support. }\end{array}$ \\
\hline Liebowitz(1998) & $\begin{array}{l}\text { Strategy adopted by senior management, KM infrastructure, knowledge ontology and repositories, } \\
\text { KM systems and tools, incentives for knowledge sharing, and collaborating /cooperating culture. }\end{array}$ \\
\hline Davenport \& Probst (2002) & $\begin{array}{l}\text { Leadership, training, measure performance well defined policy, knowledge acquisition\& sharing, IT } \\
\text { infrastructure }\end{array}$ \\
\hline Mathi(2004) & Culture, systemic processes, Knowledge Managementframework and Technological infrastructure, \\
\hline
\end{tabular}




\subsubsection{Barriers}

In a similar pattern the barriers have been shortlisted likely areas to be impacted are summarised. Refer Table 2. List of Barriers.

Interaction with experts and survey of literature facilitated the identification of EBs. These have been highlighted; Refer Table 3. Summary of Research Work for Short Listing of EBs. This also indicates contribution of a variety of researches towards short listing the EBs.

\subsection{Research Gaps}

Limited publications are available, on the relationship between Enablers and Barriers (EBs) of KM and their impact for implementation of KM in the Army.

Analyse how EBs influence the KM processes and the part they play on the dimensions of making Army Knowledge enabled.

Table 2. List of barriers $16,22,3350$

\begin{tabular}{|c|c|c|}
\hline Author ( Year) & Barriers & Focus Area \\
\hline $\begin{array}{l}\text { Pan and Scarborough } \\
(1999)^{3}\end{array}$ & Lack of trust. & Organization Culture \\
\hline $\begin{array}{l}\text { Ladd and Ward (2002) } \\
\text { and Hansen and Avital } \\
(2005)\end{array}$ & Competitiveness within an organization & Leadership, Individual \\
\hline $\begin{array}{l}\text { Bartol and Srivastava } \\
(2002))^{3} \text { and Hexmoor } \\
\text { et al. }(2006)^{\beta}\end{array}$ & Knowledge is power, perception resulting in lack of sharing has been noticed & Organization Culture \\
\hline Riege ( 2005) 阿 & $\begin{array}{l}\text { Insecurity or ignorance about the value of one's own knowledge \& a high level } \\
\text { of organisational stratification }\end{array}$ & $\begin{array}{l}\text { Individual Organisational } \\
\text { Structure }\end{array}$ \\
\hline $\begin{array}{l}\text { Organisational Struc- } \\
\text { ture }\end{array}$ & $\begin{array}{l}\text { Knowledge structure, transfer, organizational culture, motivational practices, } \\
\text { technical \& organizational infrastructure,\& senior management support. }\end{array}$ & $\begin{array}{l}\text { Leadership Organisation } \\
\text { Culture }\end{array}$ \\
\hline Goman (2002) & $\begin{array}{l}\text { "Unconscious competence", as referred to it; zero tolerance ; and a low readi- } \\
\text { ness to accept new ideas }\end{array}$ & $\begin{array}{l}\text { Leadership Organisation } \\
\text { Culture }\end{array}$ \\
\hline Ladd and Ward (2002) 阳 $^{\beta}$ & Bureaucracy & Leadership \\
\hline $\begin{array}{l}\text { Stevens, (2000) } \\
\text { Skyrme (2002) }\end{array}$ & Employee and employer goal divergence; functional silos & $\begin{array}{l}\text { Leadership Organisation } \\
\text { Culture }\end{array}$ \\
\hline $\begin{array}{l}\text { Figallo and Rhine } \\
(2002) \text { A }\end{array}$ & Lack of top management support & Leadership \\
\hline Stoddart (2001) & Lack of commitment and strategy, & $\begin{array}{l}\text { Leadership Organisation } \\
\text { Culture }\end{array}$ \\
\hline $\begin{array}{l}\text { Carr et al. (2003) } \mathrm{H}^{\text {and }} \text { and } \\
\text { Hexmoor et al. }(2006)^{\beta}\end{array}$ & Security requirements & Organition Culture \\
\hline $\begin{array}{l}\text { Erwin and Tiron } \\
(2002) \text { 同 }\end{array}$ & $\begin{array}{l}\text { Closed information environment, lack of trust; the need for extreme caution } \\
\text { as inappropriate information might endanger a current mission }\end{array}$ & Organisation Culture \\
\hline $\begin{array}{l}\text { French and Michael }{ }^{\mid 5} \\
(2003) \text { and Riege } \\
(2005)^{\beta}\end{array}$ & Power struggle or control of the use of the knowledge or information, & $\begin{array}{l}\text { Leadership Organisation } \\
\text { Culture }\end{array}$ \\
\hline Lichtblau (2003) & $\begin{array}{l}\text { Sharing amongst different agencies as different types of software \& databases } \\
\text { are used }\end{array}$ & $\begin{array}{l}\text { Leadership Organisation } \\
\text { Culture }\end{array}$ \\
\hline Kellogg (2003) & $\begin{array}{l}\text { Closed information environment, (US Defence Department) hierarchical } \\
\text { organizational structures }\end{array}$ & Organisation Structure \\
\hline $\begin{array}{l}\text { Davidson and Voss } \\
(2002))^{19} \text {; Figallo and } \\
\text { Rhine (2002) }\end{array}$ & Lack of training in both technical and interpersonal skills. & Leadership \\
\hline $\begin{array}{l}\text { Skyrme (2002) } \mathrm{H}^{11} \text { : Stod- } \\
\text { dart (2001) }\end{array}$ & $\begin{array}{l}\text { Lack of tools and/or inadequate information systems, poor information qual- } \\
\text { ity }\end{array}$ & Technology \\
\hline Davenport (1997) & $\begin{array}{l}\text { Overpopulation of the knowledge management systems with non-essential } \\
\text { information. }\end{array}$ & Technology \\
\hline $\begin{array}{l}\text { Lunney(2002) })^{\text {bj } ; \text { Stod- }} \\
\text { dart }(2001)^{13}\end{array}$ & Lack of time and resources & Organisation Climate \\
\hline
\end{tabular}


Table 3. Summary of research work for short listing of knowledge management enablers/bariers EBs

\begin{tabular}{|c|c|c|c|c|c|c|c|c|c|}
\hline Enablers/ Barriers & $\begin{array}{c}\text { Role of } \\
\text { Leadership }\end{array}$ & $\begin{array}{l}\text { Technologi- } \\
\text { cal Infra- } \\
\text { structure }\end{array}$ & $\begin{array}{c}\text { Guidelines } \\
\text { Processes } \\
\text { SOPs } \\
\end{array}$ & $\begin{array}{c}\text { Organi- } \\
\text { zation } \\
\text { structure }\end{array}$ & $\begin{array}{l}\text { Organi- } \\
\text { zation } \\
\text { culture } \\
\end{array}$ & $\begin{array}{l}\text { Incentive } \\
\text { for Imple- } \\
\text { mentation }\end{array}$ & \begin{tabular}{c|} 
Short \\
Tenures
\end{tabular} & $\begin{array}{l}\text { Own- } \\
\text { ership }\end{array}$ & $\begin{array}{c}\text { Aware- } \\
\text { ness }\end{array}$ \\
\hline Authors & 1 & 2 & 3 & 4 & 5 & 6 & 7 & 8 & 9 \\
\hline $\begin{array}{l}\text { Arthur Anderson And APQC } \\
(1996)^{2}\end{array}$ & $\sqrt{ }$ & $\sqrt{ }$ & & & $\sqrt{ }$ & & & & \\
\hline Earl, M. J. (1997) & & $\sqrt{ }$ & & & $\sqrt{ }$ & & $\sqrt{ }$ & $\sqrt{ }$ & $\sqrt{ }$ \\
\hline Skyme \& Amidon ( 1997$)^{|1|}$ & $\sqrt{ }$ & $\sqrt{ }$ & & & $\sqrt{ }$ & & & & \\
\hline $\begin{array}{l}\text { Holsapple, C. W., \& Joshi, K. } \\
\text { D. }(2000))^{\text {月 }}\end{array}$ & $\sqrt{ }$ & & & $\sqrt{ }$ & $\sqrt{ }$ & $\sqrt{ }$ & & & \\
\hline $\begin{array}{l}\text { Skyrme (2002) })^{2} \text {; Stoddart } \\
(2001)^{\text {A }}\end{array}$ & & $\sqrt{ }$ & & & & $\sqrt{ }$ & & & \\
\hline Davenport (1997); & & $\sqrt{ }$ & & & & $\sqrt{ }$ & & & \\
\hline Davenport et al. ( 1998$)^{p 9}$ & & $\sqrt{ }$ & $\sqrt{ }$ & & $\sqrt{ }$ & & & & \\
\hline Liebowitz ( 1999$)^{30}$ & $\sqrt{ }$ & $\sqrt{ }$ & & & $\sqrt{ }$ & $\sqrt{ }$ & & & \\
\hline $\begin{array}{l}\text { Arthur Andresen Business } \\
\text { Consulting ( 1999) }\end{array}$ & & $\sqrt{ }$ & & & $\sqrt{ }$ & & $\sqrt{ }$ & $\sqrt{ }$ & $\sqrt{ }$ \\
\hline APQC $(1999)^{25}$ & $\sqrt{ }$ & $\sqrt{ }$ & & & $\sqrt{ }$ & & & & \\
\hline Pan and Scarborough (1999) & & & & & $\sqrt{ }$ & & $\sqrt{ }$ & $\sqrt{ }$ & $\sqrt{ }$ \\
\hline Stoddart $(2001)^{1^{13}}$ & $\sqrt{ }$ & & & & $\sqrt{ }$ & $\sqrt{ }$ & & & \\
\hline $\begin{array}{l}\text { Lunney }(2002)^{50} ; \text { Stoddar } \\
(2001)^{\text {月 }}\end{array}$ & & & & & $\sqrt{ }$ & & & & \\
\hline Davenport \& Probst ( 2002) & $\sqrt{ }$ & & $\sqrt{ }$ & & $\sqrt{ }$ & & & & \\
\hline Goman $(2002)^{\beta-19}$ & $\sqrt{ }$ & & & & $\sqrt{ }$ & $\sqrt{ }$ & & & \\
\hline Ladd and Ward (2002) & $\sqrt{ }$ & & & & & $\sqrt{ }$ & & & \\
\hline $\begin{array}{l}\text { Skyrme (2002) 居; Stevens, } \\
(2000)\end{array}$ & $\sqrt{ }$ & & & & $\sqrt{ }$ & $\sqrt{ }$ & & & \\
\hline Figallo and Rhine (2002) & $\sqrt{ }$ & & & & & & & & \\
\hline Erwin and Tiron (2002) & & & & & $\sqrt{ }$ & & & & \\
\hline Lichtblau (2003) & $\sqrt{ }$ & & & & $\sqrt{ }$ & $\sqrt{ }$ & & & \\
\hline Kellogg $(2003)^{A 2}$ & & & & $\sqrt{ }$ & & & & & \\
\hline Mathi ( 2004 ) 疬 & & $\sqrt{ }$ & $\sqrt{ }$ & & $\sqrt{ }$ & $\sqrt{ }$ & & & \\
\hline $\begin{array}{l}\text { Ladd and Ward (2002) } \\
\text { Hansen and Avital (2005) }\end{array}$ & $\sqrt{ }$ & & & & $\sqrt{ }$ & $\sqrt{ }$ & $\sqrt{ }$ & $\sqrt{ }$ & $\sqrt{ }$ \\
\hline Riege (2005) & & & & $\sqrt{ }$ & & $\sqrt{ }$ & $\sqrt{ }$ & $\sqrt{ }$ & $\sqrt{ }$ \\
\hline $\begin{array}{l}\text { French and Michael (2003)咸 } \\
\text { and Riege (2005) }\end{array}$ & $\sqrt{ }$ & & & & $\sqrt{ }$ & & & & \\
\hline 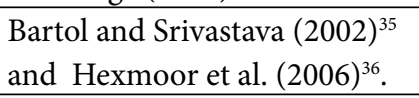 & & & & & $\sqrt{ }$ & & $\sqrt{ }$ & $\sqrt{ }$ & $\sqrt{ }$ \\
\hline $\begin{array}{l}\text { Carr et al. (2003) } \\
\text { moor et al. (2006) }\end{array}$ & & & & & $\sqrt{ }$ & $\sqrt{ }$ & & & \\
\hline Chia, R., \& Holt, R. (2008) & & & & & & & $\sqrt{ }$ & & $\sqrt{ }$ \\
\hline $\begin{array}{l}\text { Ede, M. C., \& Mohamed, S. } \\
(2011) \text { 同 }^{\text {. }}\end{array}$ & $\sqrt{ }$ & & & & $\sqrt{ }$ & $\sqrt{ }$ & & & \\
\hline $\begin{array}{l}\text { Abdul-Rahman, H., \& Wang, } \\
\text { C. }(2010)^{2]}\end{array}$ & $\sqrt{ }$ & $\sqrt{ }$ & $\sqrt{ }$ & & $\sqrt{ }$ & $\sqrt{ }$ & & & \\
\hline Chong, S. C. et al. (2011) & $\sqrt{ }$ & & $\sqrt{ }$ & $\sqrt{ }$ & $\sqrt{ }$ & & $\sqrt{ }$ & $\sqrt{ }$ & $\sqrt{ }$ \\
\hline $\begin{array}{l}\text { Al-Hakim, L.A. Yousif, A. Y., } \\
\text { \& Hassan, S. (2011) }\end{array}$ & $\sqrt{ }$ & & $\sqrt{ }$ & $\sqrt{ }$ & $\sqrt{ }$ & & & & \\
\hline
\end{tabular}




\subsection{Research Objective}

Considering the issues related to Knowledge Management the salient objectives of this Research Proposal in the context of the Army is as follows:-

To identify the enablers and barriers of Knowledge Management.

ISM Modelling. Interpretive Structural Modeling (ISM)䍏

The modalities involve :

- Structuring of final outcome in a hierarchical order.

- Their inter-se relationship

- Driving and Dependence Powers.

- Level Partitions and Classifications

\section{Research Design.}

\subsection{Research Design is discussed in the succeeding paragraph.}

Experts Opinion Senior Officers of the Army who have been associated with the establishment for over 25 years were involved in short listing the factors.

Respondents In addition, to assess, the functional level activities, primary source of data were Junior Officers of the Army (Rank of Captain \& Majors below 10 Years of Service). Their perception, organisation structure and culture in the implementation of KM was sought through questionnaire.

Samples Random sampling technique has been used. Here we selected a group of subjecti.e. sample from a larger group i.e. population. A Sample Size of 65 Army Officers was utilised.

Method of Investigation In the context of the subject, respondents were appropriately identified maintaining randomness.

Questionnaire Design The questionnaire uses five point rating scale which was divided into five parts. Part 1 is related to Information Capture, Retention and Access; Part 2 On Information Sharing; Part 3 is related to Technology; Part 4 focused on Organisation Climate,while, Part 5 was linked to the Implementation.

\subsection{Interpretive Structural Modelling (ISM)}

ISM methodology identifies complexities, defines the order and direction of relationships among elements of a system. Graphical interpretation of complex but definite relationship is the final outcome of this method.

\subsubsection{The sequence of action for ISM process is}

- Identify key elements relevant to the issues with help of experts and survey

- Establish a one to one contextual relationship between elements.

- A structural self-interaction matrix also known as SSIM is evolved using two elements at a time based on the relationship between them.

- Next, from the above SSIM, create a reachability matrix.

- Reachability Matrix is tested for transitivity of the contextual relation. This concept is explained in detail subsequently.

- Partition the reachability matrix into an hierarchy;

- Directed graph (digraph)based on the relationships is depicted after removing transitivity from reachability matrix.

- Convert, resultant digraph into an ISM-based model by replacing factors with the statements.

- Finally, check model for inconsistency.

The details of KM Enablers and Barriers (EBs) that would be tested in the current research is tabulated,please refer Table4. Knowledge Management Enablers/Barriers (EBs) Shortlisted for this Research.

Table 4. Knowledge management enablers/ barriers (EBs) shortlisted for this research

\begin{tabular}{ll}
\hline EB Number & Description \\
\hline 1. & Role of Leadership \\
2. & Technological infrastructure \\
3. & Guidelines and Processes SoPs \\
4. & Organizational structure \\
5. & Organizational culture \\
6. & Incentives for Implementation \\
7. & Short Tenures \\
8. & Ownership \\
9. & Awareness \\
\hline
\end{tabular}


Table 5. Structural self-interaction matrix (SSIM)

\begin{tabular}{|c|c|c|c|c|c|c|c|c|c|c|}
\hline EB Number & Description & \multicolumn{9}{|c|}{ EB Number } \\
\hline & & 9 & 8 & 7 & 6 & 5 & 4 & 3 & 2 & 1 \\
\hline 1 & Role of Leadership & $\mathrm{V}$ & $\mathrm{V}$ & $\mathrm{V}$ & $\mathrm{V}$ & $\mathrm{V}$ & $\mathrm{V}$ & $\mathrm{V}$ & $\mathrm{V}$ & $\mathrm{X}$ \\
\hline 2 & Technological infrastructure & $\mathrm{V}$ & $\mathrm{V}$ & $\mathrm{V}$ & $\mathrm{V}$ & $\mathrm{V}$ & A & A & $\mathrm{X}$ & A \\
\hline 3 & Guidelines \& Processes SoPs & $\mathrm{V}$ & $\mathrm{V}$ & $\mathrm{V}$ & $\mathrm{V}$ & $\mathrm{V}$ & $\mathrm{X}$ & $\mathrm{X}$ & $\mathrm{V}$ & $\mathrm{A}$ \\
\hline 4 & Organizational structure & $\mathrm{V}$ & $\mathrm{V}$ & $\mathrm{V}$ & $\mathrm{O}$ & $\mathrm{V}$ & $\mathrm{X}$ & $\mathrm{X}$ & $\mathrm{V}$ & $\mathrm{A}$ \\
\hline 5 & Organizational culture & $\mathrm{X}$ & $\mathrm{V}$ & $\mathrm{V}$ & $\mathrm{X}$ & $\mathrm{X}$ & A & A & A & $\mathrm{A}$ \\
\hline 6 & Incentives for Implementation & $\mathrm{V}$ & $\mathrm{V}$ & $\mathrm{V}$ & $\mathrm{X}$ & $\mathrm{X}$ & $\mathrm{O}$ & $\mathrm{A}$ & A & A \\
\hline 7 & Short Tenures & $\mathrm{O}$ & $\mathrm{V}$ & $\mathrm{X}$ & A & $\mathrm{A}$ & $\mathrm{A}$ & $\mathrm{A}$ & $\mathrm{A}$ & $\mathrm{A}$ \\
\hline 8 & Ownership & A & $\mathrm{X}$ & A & A & A & A & $\mathrm{A}$ & A & A \\
\hline 9 & Awareness & $\mathrm{X}$ & $\mathrm{V}$ & $\mathrm{O}$ & A & $\mathrm{X}$ & $\mathrm{A}$ & $\mathrm{A}$ & A & $\mathrm{A}$ \\
\hline
\end{tabular}

\subsection{Structural Self-Interaction Matrix (SSIM)}

The VAXO Matrix as developed, refer Table 5. Structural Self-interaction matrix (SSIM), is a result of interaction with a group of senior officers of the army and academicians of repute. Relevance and grouping of shortlisted Enablers / Barriers wereitrated basedon theircontextual relationship.

The rule for constructing the SSIM is :-

- $\quad \mathrm{V}-\mathrm{EB}(\mathrm{i})$ influences $E B(\mathrm{j})$

- $\quad A-E B(j)$ influences $E B(i)$

- $\quad \mathrm{X}-\mathrm{EB}(\mathrm{i})$ and $\mathrm{EB}(\mathrm{j})$ will complement /influence each other;

- $\mathrm{O}-\mathrm{EB}(\mathrm{i})$ andEB(j)are unrelated.

$\cdot$

\subsection{Reachability Matrix}

Initial reachability matrix is evolved by binary substitution of $\mathrm{V}, \mathrm{A}, \mathrm{X}, \mathrm{O}$ by 0,1 in the SSIM. The rule for substitution to be followed is as follows:-

- All Vs will be substituted by 1 and the reciprocating A will be substituted by 0 ;

- All As will be substituted by 0 and the reciprocating V will be substituted by 1 ;

- All Xs will be substituted by 1 . And All Os will be substituted by 0 .

Final Reachability Matrix To arrive at the final reachability matrix the concept of transitivity is to be understood. This is explained using the example referred in Figure 1. Transitivity.

- Consider factor ' $x$ ' relates to factor ' $y$ 'and ' $y$ ' relates to factor' 'z'.

- Term transitivity implies factor ' $\mathrm{x}$ ' is also related to factor ' $\mathrm{z}$ '.
- Similarly factor ' $x$ ' relates to factor ' $w$ ' implies, factor ' $w$ ' relates to factor ' $y$.

- Since, ISM approach is based on expert opinion, conceptual inconsistency is detected in a qualitative way, in case of on such complex relationships.

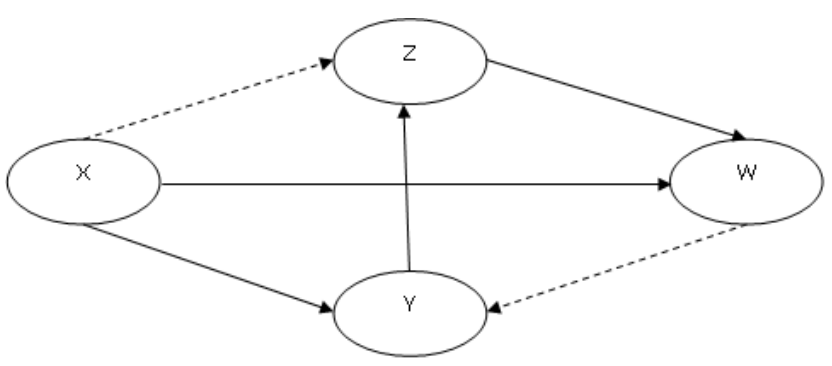

Figure 1. Transitivity.

Since, there was no transitivity;now, initial reachability matrix has been used for further analysis. Tabulated summary of driving power and the dependence power can be referred in Table 6. Initial Reachability Matrix (Driving \& Dependence Power).

- Summation of all elements horizontally indicates the driving power.

- Summation of all elements attributes vertically indicates dependence power.

\subsection{Levels of Partitions}

A total of five iterations is noticed refer Table 7. Levels of Partitions.

- The final reachability matrix culminates in the formation of the reachabilityset and antecedent set for each EB.

- The reachability set, consists of all factors (including itself) and those that it influences to achieve the outcome. 
Table 6. Initial reachability matrix (Driving \& Dependence Power)

\begin{tabular}{|l|l|c|c|c|c|c|c|c|c|c|c|}
\hline EB Number & Description & \multicolumn{9}{|c|}{ EB Number } & Driving Power \\
\hline & & 9 & 8 & 7 & 6 & 5 & 4 & 3 & 2 & 1 & \\
\hline 1 & Role of Leadership & 1 & 1 & 1 & 1 & 1 & 1 & 1 & 1 & 1 & 9 \\
\hline 2 & Technological infrastructure & 1 & 1 & 1 & 1 & 1 & 0 & 0 & 1 & 0 & 6 \\
\hline 3 & Guidelines and Processes SoPs & 1 & 1 & 1 & 1 & 1 & 1 & 1 & 1 & 0 & 8 \\
\hline 4 & Organizational structure & 1 & 1 & 1 & 0 & 1 & 1 & 1 & 1 & 0 & 7 \\
\hline 5 & Organizational culture & 1 & 1 & 1 & 1 & 1 & 0 & 0 & 0 & 0 & 5 \\
\hline 6 & Incentives for Implementation & 1 & 1 & 1 & 1 & 1 & 0 & 0 & 0 & 0 & 5 \\
\hline 7 & Short Tenures & 0 & 1 & 1 & 0 & 0 & 0 & 0 & 0 & 0 & \\
\hline 8 & Ownership & 0 & 1 & 0 & 0 & 0 & 0 & 0 & 0 & 0 & \\
\hline 9 & Awareness & 7 & 9 & 7 & 5 & 7 & 3 & 3 & 4 & 1 & \\
\hline & Dependence Power & & 1 & 0 & 0 & 1 & 0 & 0 & 0 & 0 & \\
\hline
\end{tabular}

Table 7. Level Partitions

\begin{tabular}{|c|c|c|c|c|c|c|c|c|c|}
\hline \multirow[t]{2}{*}{ EB Number } & Description & \multicolumn{3}{|c|}{ Reachability Set } & \multicolumn{3}{|c|}{ Antecedent Set } & Intersection & \multirow[t]{2}{*}{ Level } \\
\hline & \multicolumn{8}{|c|}{ Total number of Iterations 5} & \\
\hline 1 & Role of Leadership & \multicolumn{3}{|c|}{$1,2,3,4,5,6,7,8,9$} & \multicolumn{3}{|c|}{1} & 1 & VI \\
\hline 2 & Technological infrastructure & \multicolumn{3}{|c|}{$2,5,6,7,8,9$} & \multicolumn{3}{|c|}{$1,2,3,4$} & 2 & IV \\
\hline 3 & Guidelines and Processes SoPs & \multicolumn{3}{|c|}{$2,3,4,5,6,7,8,9$} & \multicolumn{3}{|c|}{$1,3,4$} & 3,4 & $\mathrm{~V}$ \\
\hline 4 & Organizational structure & \multicolumn{3}{|c|}{$2,3,4,5,7,8,9$} & \multicolumn{3}{|c|}{$1,3,4$} & 3,4 & $\mathrm{~V}$ \\
\hline 5 & Organizational culture & \multicolumn{3}{|c|}{$5,6,7,8,9$} & \multicolumn{3}{|c|}{$1,2,3,4,5,6,9$} & $5,6,9$ & III \\
\hline 6 & Incentives for Implementation & \multicolumn{3}{|c|}{$6,7,8,9$} & \multicolumn{3}{|c|}{$1,2,3,5,6$} & 6 & III \\
\hline 7 & Short Tenures & \multicolumn{3}{|c|}{7,8} & \multicolumn{3}{|c|}{$1,2,3,4,5,6,7$} & 7 & II \\
\hline 8 & Ownership & \multicolumn{3}{|c|}{8} & \multicolumn{3}{|c|}{$1,2,3,4,5,6,7,8,9$} & 8 & $\mathrm{I}$ \\
\hline \multirow[t]{3}{*}{9} & Awareness & \multicolumn{3}{|c|}{$5,8,9$} & \multicolumn{3}{|c|}{$1,2,3,4,5,6,9$} & 5,9 & II \\
\hline & Level & $\mathrm{I}$ & II & III & IV & $\mathrm{V}$ & VI & & \\
\hline & Elimination & 8 & $5,9,7$ & 6 & 2 & 3,4 & 1 & & \\
\hline
\end{tabular}

- Antecedent set is defined asall factors, that it gets influenced by including itself to achieve the outcome,

- Intersection of these sets is determined for all the EBs.

- EBs which hasreachability set valueequal to intersectionset valuethen, they occupy the top level in the ISM hierarchy.

- Thus, the top mostlevel factorwillassist any other factor above its own level.

- Now this top most level factoris separated from the rest.

- This process if repeated for the next level and similar iterations for subsequent levels.

- Thus, each factorhas a definite level.Then,diagraph and the final ISM modelare built based on these levels.

\subsection{ISM Digraph and Model}

The initial reachability matrix leads to structural model.
Initial directed graph, or initial digraph is a diagrammatic representation of the relationship between any two EBs, asshown by an arrow which points from one to the other. Elimination oftransitivity (refer the ISM methodologypara 4 above)leads to the final digraph refer Figure 2: Final digraph depicting the relationship among the KM EBs.

This is now used to develop further to generate the ISM-based model refer Figure 3. ISM Based Model.

\subsection{MICMAC Analysis and Classification of EBs}

MICMAC (Matrice d'Impacts. Croisés-Multiplication Appliquée à un Classement i.e. Cross impact matrix multiplication applied to classification) is abbreviated as MICMAC. Sharma et a ${ }^{57}$, has conveyed that "the principle is based on multiplication properties of matrices". MICMAC analysis is the tool for arriving at the driving power and dependence power of each of the EBs.

Grouping of KM Enablers and Barriers is evident. 


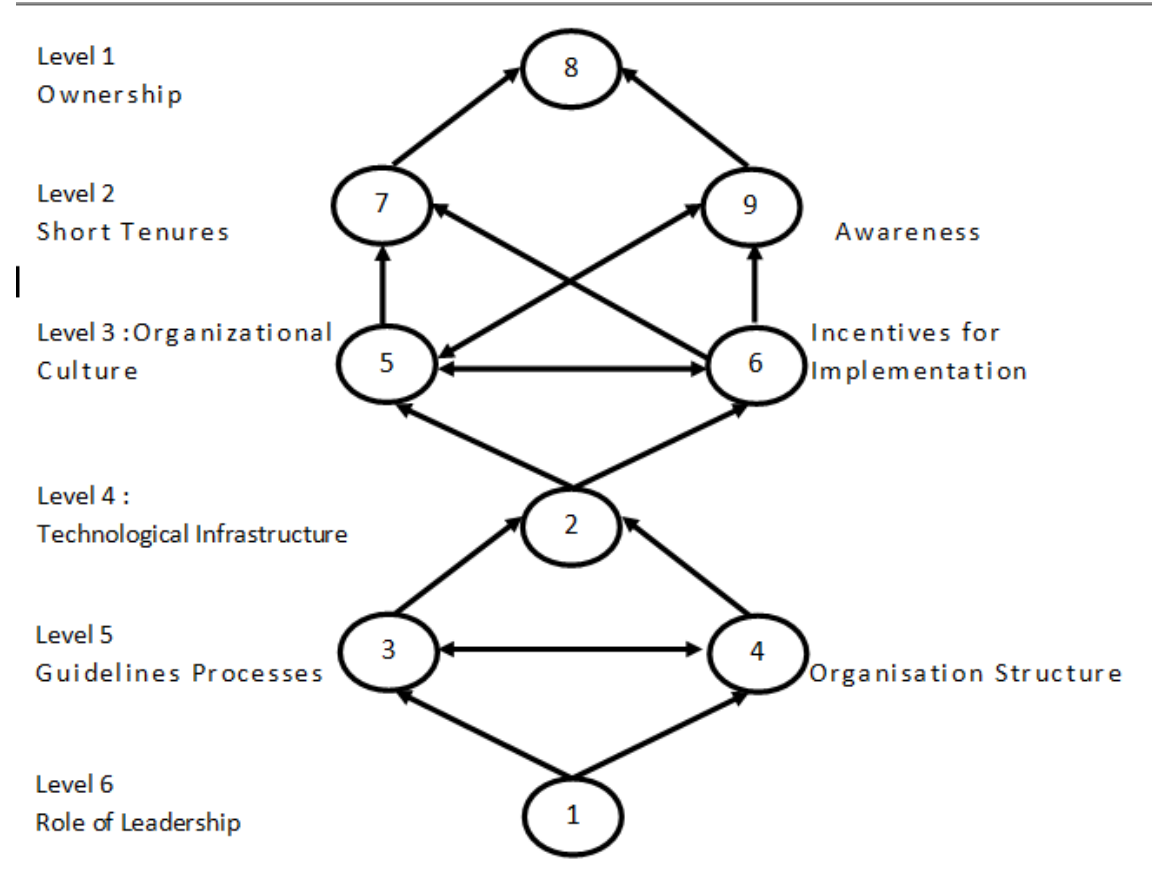

Figure 2. Final digraph depicting the relationship among the KM Ebs.

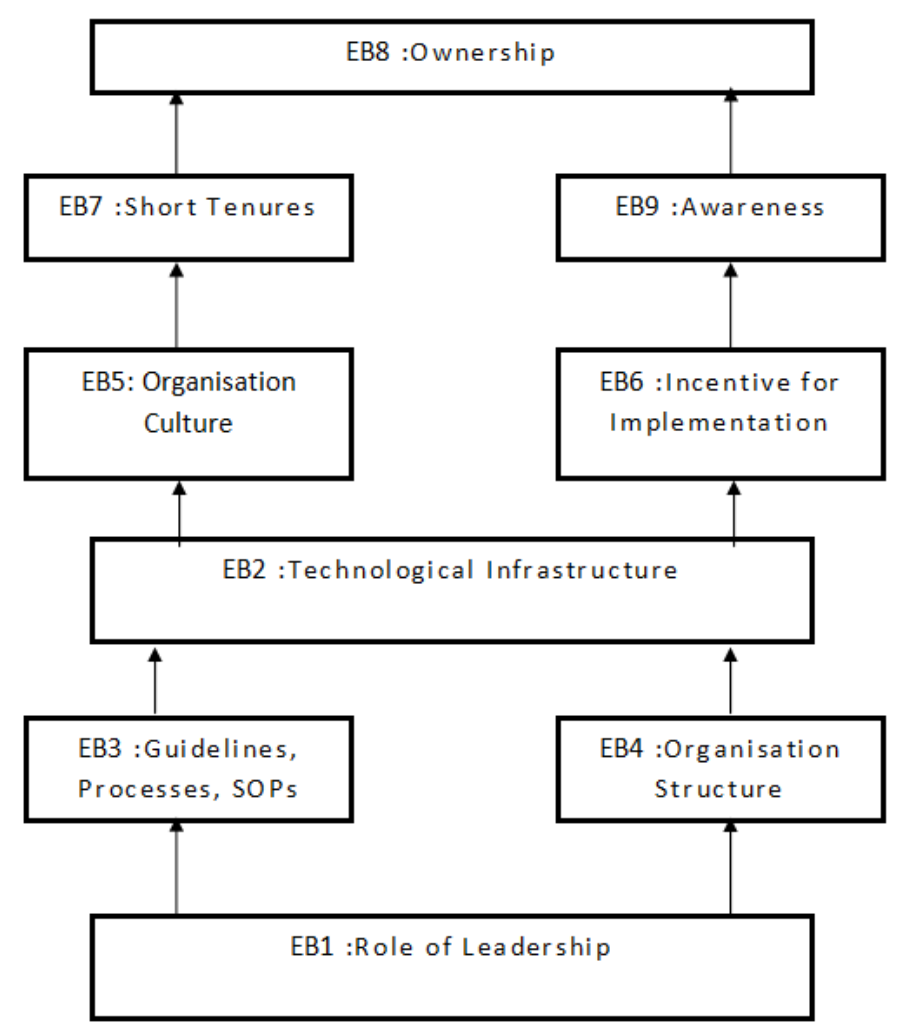

Figure 3. ISM based model. 
Refer Figure 4 Cluster of KM Enablers and Barriers.

The figure has four Quadrants. First quadrant has "Autonomous EBs"; second quadrant conveys "Dependent EBs"; third quadrant includes "Linkage EBs"; fourth quadrant contains "Driver EBs." The EBs are categorised as used by

\section{Analysis and Findings}

\subsection{Compendious}

The ultimate aim of ISM with MICMAC analysis has been to identify the priorities of factors considered based on their inter-relationships. The essence of this classification of EBs is to arrive at the driving power and dependence power of each EBs and its status.

For example it is observed that EB1 has a driving power of 9 and a dependence power of 1(Refer Table 6: Initial Reachability Matrix ( Driving \& Dependence Power). This has been depicted in cluster 4 shown in Figure 3. ISM Based Model.

The priorities that emerged and can be classified as follows:-

Quadrant I Autonomous. This quadrant consists of autonomous EBs (low"driving power", low"dependence power"). These EBs are relatively disassociated from other; in the current context no autonomous EBs exists.

Quadrant II Dependent This quadrant has EBs ("low driving power","high dependence power"). In the present case, EB7 Short Tenures, EB8 Ownership and EB9 Awareness are in this category.

Quadrant III Linkage In the Third quadrant EBs ("high driving'”' dependence power"). These EBs will have influence on other EBs with reverse effect on themselves. In this case, EB5 Organisation Culture and EB6 Incentive for Implementation fall in this Category.

Quadrant IV Independent/ Drivers The fourth quadrant contains independent EBs ("very high driving power", "low dependence power"). In this case, EB1 Role of Leadership, EB2 Technological Infrastructure; EB3 Guidelines Processes SOPs; EB4 Organisation Structure are in this category.

\subsection{Discussion}

In reality, understanding the status or hierarchy of EBs indicate the modus operandi for successful KM implementation.

EB1 Role of Leadership and its commitment is most significant EB as it has its strong driving power

\section{Cluster of KM Enablers/ Barriers(EB)}

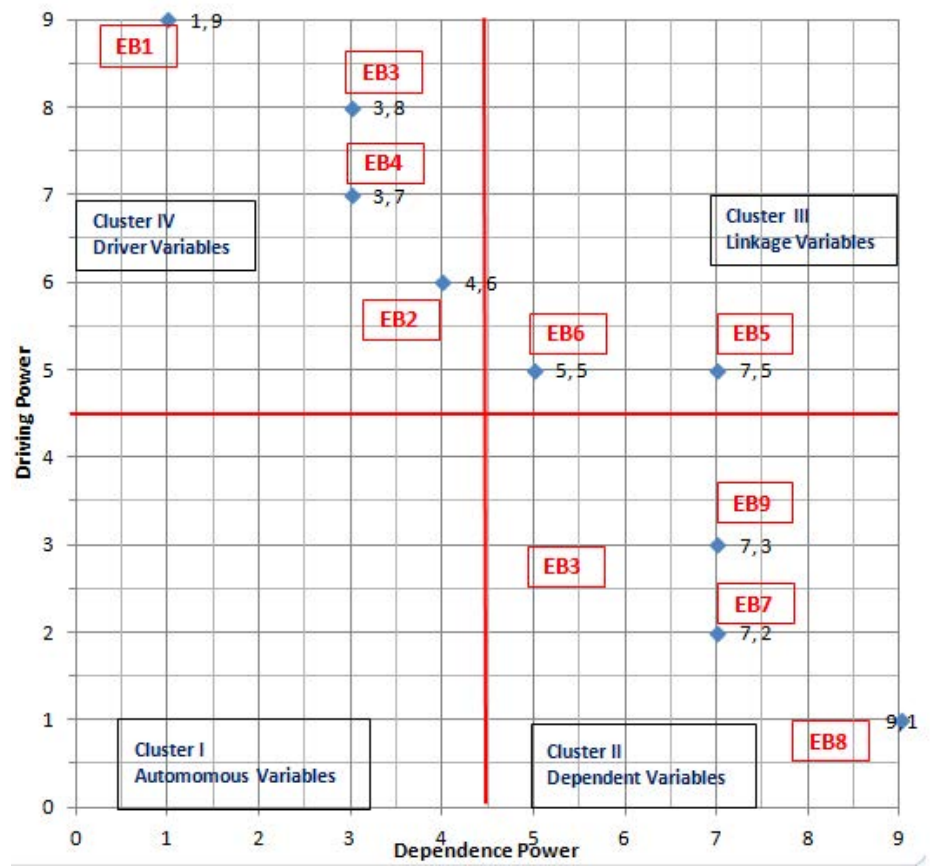

Figure 4. Cluster of KM enablers and barriers. 
and weak dependence power. In the ISM Model, EB1 is thus positioned at the lowest level. This implies that this element drives the KM process. If and when it plays a pivotal role, then success is guaranteed or else, i.e. lack of leadership will result in insurmountable barrier for KM to flourish.

Similarly, EB3- Guidelines, processes and SOPs \& EB4- Organisation Structure are placed at the fifth level with strong driving power \& weak dependence power. In the Army, a well-defined hierarchy already exists and stringent adherence to SOPs \& polices contribute towards uniformed standards. Therefore, they play an important role in KM implementation.

EB2 Technical Infrastructure is independently positioned at Level Four. This is an enabler, a tool and a facilitator. It acts as a catalyst \&assists in making the working condition of sharing, archival \& retrieval user friendly.

EB5 Organisation Culture \& EB6 Incentives for Implementation (Level Three); Their, High Driving power \& Higher Dependence power, should be nurtured by the Military Establishments. The establishment must encourage $\mathrm{KM}$ implementation with incentives. Also create an Organisation Culture for sharing \& handling information on "Need to Know" basis.

Also, EB2 Technology Infrastructure, EB5Organisation Culture and EB6 Incentive for Implementation are termed as "strategic barriers"as they are found to be in the third and fourth levels of the ISM model.

They are key elements in knowledge sharing, support communication, collaboration, and encourage quest for knowledge and information.

These EBs require senior leader intervention for KM success.

EB7 Short Tenures \& EB9 Awareness. These EBs are at level two with weak driving power strong dependence power. Both depend on the drivers to influence them. In a military environment transfers are frequent, the knowledge / wisdom shared in the form of Handing Taking over notes alone is not adequate. Since, dependence power is high, need for drivers like leadership, structure, process, using technology must lend itself to create awareness \& overcome the challenges of short tenures.

Similarly, EB8 Ownership issues with strong dependence power and weak driving power is positioned at the uppermost level. This indicates that the drivers must ensure that each \& every member is committed and accountable. Ownership must be encouraged to the extent that an individual on his own free will enjoys \& cultivates the essence of KM process.

In MICMAC Diagram (Refer Figure 4) we notice that there is no autonomous EBs; this means that there are no weak drivers and weak dependents. Thus, it can be concluded that all the balance EBs are relevant and the degree of importance as critical success factors for KM implementation in the army.

\section{Conclusion and Future Directions}

Enablers and Barriers, based on their relative levels, are the key in the KM implementation process. It can also be observed from Figure 4 that conclusively, all nine EBs are relevant although they exhibit a varying degree of relative importance. The four critical EBs are Role of Leadership, Guidelines, processes and SOPs, Organizational structure and Technological Infrastructure.

Way Ahead. It is recommended that future research could use this method for initial model (ISM). Then quantify the framework obtained from ISM model using Analytical hierarchy process (AHP). In addition, there will be a definite need to focus on:-

Firstly, driving power factors; such as sub-centers of Leadership, next, areas which require changes in the Organisation hierarchy and lastly, modification to processes \& SoPs which will accommodate KM in the Army.

Secondly, the dependence Power sub-centers of Ownership, challenges of short tenures and methods to introduce incentives togive impetus, for KM to succeed.

Thirdly, impact of "Continuity or truncated tenures"; "Ownership and Awareness" at functional direction \& conceptual levels in the Armed Forces, need to be further researched.

\section{References}

1. Chinowsky P, Carrillo P. Knowledge Management to Learning Organization Connection. Journal of Management In Engineering (C) ASCE, 2007; 23(3):122-30.

2. Dariush R, Khosro E, Eghbal HS, Morad AN. Providing An Applied Model For Knowledge Management Development Planning In Military Organizations: Providing Proposed Methodology For NAJA, Kuwait.Arabian Journal of 
Business and Management Review . 2014Sept; 4(1):1-9.

3. Chattopadhyay SP. Management education reform in a knowledge management Environment. Journal of American Academy of Business. 2007; 11(1):168-72.

4. Bennet A, Bennet D. Moving from Knowledge to Wisdom: From Ordinary Consciousness to Extraordinary Consciousness. VINE Journal of Information and Knowledge Management Systems 2008; 38(1):7-15.

5. Deng L, Poole MS. Learning Through ICT-Enabled Social Networks. International Journal of Information Technology and Management.2008; 7(4):374-91.

6. Bozbura F. Knowledge Management Practices in Turkish SMEs. Journal of Enterprise, Information, Management, 2007,;20( 2):209-21.

7. Boh WF. Mechanisms for Sharing Knowledge in Project-Based Organizations. Information and Organization. 2007; 17(1):27-58.

8. Pillania RK. Information Technology Strategy for Knowledge Management in SMEs. Knowledge and Process Management. 2008;15(3):203-10.

9. Ooi K B. TQM and Knowledge Management: Literature Review and ProposedFramework. African Journal of Business Management. 2009;3(11): 633-43.

10. Zollo G, Iandoli L. Organizational Cognition and Learning. Building Systems for the Learning Organization. New York:Information Science Publishing; 2007; p .362.

11. Evangelista P, Esposito E, Lauro V, Raffa M. The Adoption of Knowledge Management Systems in Small Firms. Electronic Journal of Knowledge Management. 2010; 8(1): $1-10$.

12. Sage A. Interpretive Structural Modeling: Methodology for Large-scale Systems. New York: McGraw-Hill.1997. p. 91-164.

13. Warfield J. Developing interconnection matrices in structural modeling. IEEE Transactionsons on Systems, Manand Cybernetics.2005; 4(1):81-67.

14. Pillania RK. Leveraging Knowledge for Sustainable Competitiveness in SMEs. International Journal of Global and Small Business. 2006; 1(4):393-406.

15. Khalil O, Claudio A, Seliem A. Knowledge Management: The Case of the Acushnet Company. SAM Advanced Management Journal,.2006; 71(3):34-50.

16. Hansen S, Avital M. Contributing your wisdom or showing your cards? A quantitative inquiry of knowledge sharing behaviour. 2005.

17. Hong C, Goh T, Hooper V. Knowledge and information sharing in a closed information environment. Journal of Knowledge Management.2009;13(2):21-34.

18. Armin A, Alamdari A, Sohrab. knowledge management and innovation strategy in defensive organizations. Political Science Quarterly. 2010;19:73-90

19. Jones NB, Mahon JF. Nimble knowledge transfer in high velocity/ turbulent environments. Journal of Knowledge Management. 2012; 16(5):774-88.

20. Bennet A, Bennet D, Lee SL. Exploring the military contribution to KBD through leadership and values.Journal of
Knowledge Management. 2010;14(2):314-330.

21. Abdul-Rahman $\mathrm{H}$, Wang C. Preliminary approach to improve knowledge management in engineering management. Scientific Research and Essays. 2010; 5(15):1950-64.

22. Erwin SI, Tiron R. Success of lessons learned process based on truthfulness. National Defense. 2002;87 (584).

23. Theriou N, Maditinos D, Theriou G. Knowledge Management Enabler Factors and Firm Performance: An Empirical Research of the Greek Medium and Large Firms. European Research Studies. 2011;14(2):1-38.

24. Andersen A. The American Productivity and Quality Centre.1996.

25. American Productivity and Quality Center. Knowledge management: Executive summary: Consortium Benchmarking Study Best-Practice. Report, APQC. Houston, TX. Available from: www.apqc.org. 1999.

26. Earl MJ. Knowledge in organizations. Knowledge as strategy: Reflections on Skandia International and Shorko Films. L. (ed.). Prusak. Boston, MA: Butterworth-Heinemann, 1997.

27. Skyrme DJ.The 3Cs of knowledge sharing: culture, co-opetition and commitment. (www.skyrme.com/updates/u64_ f1.htm), Date accessed:08/2002.

28. Holsapple C W, Joshi K D. An investigation of factors that influence the management of knowledge in organizations. The Journal of Strategic Information Systems. 2002; 9(2): 235-61.

29. Davenport TH, Prusack L. Working Knowledge: How organizations manage what they know. Harvard Business School Press.1998.

30. Liebowitz J. Key ingredients to the success of an organization's knowledge management strategy. Knowledge and Process Management. 1999; 6 (1):37-40.

31. Davenport TH, Probst G. Knowledge Management Case Book. Best Practices, 2nd ed., New York: Wiley, 2002.

32. Mathi K. Key Success Factors For Knowledge Management, Lindau, Germany. MBA: International Business Management and Consulting, 2004.

33. Pan SL, Scarbrough H. Knowledge management in practice: an exploratory case study. Technology and Strategic Management. 1999; 11(3):359-74.

34. Ladd A, Ward MA. An investigation of environment factors influencing knowledge transfer. Journal of Knowledge Management Practice. 2002 Aug. Available from: (www. tlainc.com/articl38.htm

35. Bartol KM, Srivastava A. Encouraging knowledge sharing: the role of Organisational reward systems. Journal of Leadership and Organisation Studies. 2009;9(1):64-76.

36. Hexmoor $\mathrm{H}$, Wilson $\mathrm{S}$, Bhattaram $\mathrm{S}$. A theoretical inter-organizational trust-based security model.The Knowledge Engineering Review. 2006; 21(2):127-61.

37. Riege A. Three-Dozen Knowledge-Sharing Barriers Managers Must Consider. Journal of Knowledge Management. 2005; 9(3):18-35.

38. Goman CK. Five reasons people don't tell what they know. 2002 June 22. Available from: www.destinationkm.com 
39. Stevens L. Incentives for sharing. Knowledge Management Magazine. 2002 October. Available from: www.kmmag. com/articles/default.asp?ArticleID $1 / 4778$

40. Skyrme DJ, Amidon D, The Knowledge Agenda. Journal of Knowledge Management. 1997; 1(1):27-37.

41. Figallo C, Rhine N. Building the Knowledge Management Network. New York, NY: Wiley Technology Publishing. 2002.

42. Stoddart L. Managing intranets to encourage knowledge sharing: Opportunities and Constraints. Online Information Review. 2001; 25(1):19-29.

43. Carr CA, Erickson GS, Rothberg HN. Knowledge-sharing in value-chain networks: Certifying collaborators for effective protection processes. Advances in Competitiveness Research. 2003; 11(1):152-64.

44. French M, Michael S. CIA, FBI wrangle over threat center. Federal Computer Week. 2002; 17(12):8-9.

45. Lichtblau E. Agencies still fail to share information. New York Times, 200330 Apr.

46. Kellogg JK. Protecting America with information technology. Journal Signals. 2003; 57(10):35.

47. Davidson C, Voss P. Knowledge Management: An Introduction to Create Competitive Advantage from Intellectual Capital. Tandem Press, Auckland. 2002.

48. Davenport TH. Known evils: Common pitfalls of knowledge management. 2004 March 05. Available from: www. cio.com/archive/061597_think.html

49. Lunney K.NASA managers not sharing lessons learned. Available from: GovExec.com, 2002,
50. Chia R, Holt R. On managerial knowledge. Management Learning. 2008; 39(2):141-58.

51. Ede MC, Mohamed S. Mapping relationships among the enablers of knowledge management within Hong Kong construction organisations. Procedia Engineering. 2011;14:1938-44.

52. Chong SC, Salleh K, Ahmad SNS, Sharifuddin SISO. KM implementation in a public sector accounting organization: an empirical investigation. Journal of Knowledge Management. 2011; 15(3):497-512.

53. Yousif LA, AL-Hakim,, Hassan S. The role of middle managers in knowledge management implementation for innovation enhancement. International Journal of Innovation, Management and Technology. 2011;2(1):1-9.

54. Warfield JN. On arranging elements of a hierarchy in graphic form. IEEE Transactions on Systems, Man, and Cybernetics. 1973; (2):121-32.

55. Waller RJ. Application of interpretive structural modeling to priority-setting in urban systems management. Portraits of complexity. 1975; 9:104-8.

56. Sharma H D, Gupta A D , Sushil. The Objectives of Waste Management in India: A Futures Inquiry, Technology Forecast and Social Change. 1995; 48(3):285-309.

57. Mandal A, Deshmukh S. Vendor selection using interpretive structural modeling (ism). International Journal of Operations and Production Management. 1994; 14(6) pp. 52-59. 